\title{
The information system on education and the labour market developed by ROA
}

Citation for published version (APA):

Heijke, J. A. M., \& de Grip, A. (1991). The information system on education and the labour market developed by ROA. Researchcentrum voor Onderwijs en Arbeidsmarkt, Faculteit der Economische Wetenschappen. ROA Working Papers No. 2E https://doi.org/10.26481/umarow.199102E

Document status and date:

Published: 01/01/1991

DOI:

10.26481/umarow.199102E

Document Version:

Publisher's PDF, also known as Version of record

\section{Please check the document version of this publication:}

- A submitted manuscript is the version of the article upon submission and before peer-review. There can be important differences between the submitted version and the official published version of record.

People interested in the research are advised to contact the author for the final version of the publication, or visit the DOI to the publisher's website.

- The final author version and the galley proof are versions of the publication after peer review.

- The final published version features the final layout of the paper including the volume, issue and page numbers.

Link to publication

\footnotetext{
General rights rights.

- You may freely distribute the URL identifying the publication in the public portal. please follow below link for the End User Agreement:

www.umlib.nl/taverne-license

Take down policy

If you believe that this document breaches copyright please contact us at:

repository@maastrichtuniversity.nl

providing details and we will investigate your claim.
}

Copyright and moral rights for the publications made accessible in the public portal are retained by the authors and/or other copyright owners and it is a condition of accessing publications that users recognise and abide by the legal requirements associated with these

- Users may download and print one copy of any publication from the public portal for the purpose of private study or research.

- You may not further distribute the material or use it for any profit-making activity or commercial gain

If the publication is distributed under the terms of Article $25 \mathrm{fa}$ of the Dutch Copyright Act, indicated by the "Taverne" license above, 
THE INFORMATION SYSTEM ON EDUCATION

AND THE LABOUR MARKET

DEVELOPED BY ROA

ROA-W-1991/2E*

J.A.M. Heijke and A. de Grip

A contribution to the European Symposium on Labour Market Developments, Radcliffe House, University of Warwick, 30th \& 31st May 1991

* with corrections, 18-9-1991

RESEARCH CENTRE FOR EDUCATION AND LABOUR MARKET

Faculty of Economic Sciences

Rijksuniversiteit Limburg

Maastricht, June 1991 


\section{CIP-GEGEVENS KONINKLIJKE BIBLIOTHEEK, DEN HAAG}

Heijke, J.A.M.

The information system on education and the labour market developed by ROA : a contribution to the European symposium on labour market developments, Radcliffe House, University of Warwick, 30th \& 31 st May 1991 / J.A.M. Heijke and A. de Grip. - Maastricht : Research Centre for Education and Labour Market, Faculty of Economic Sciences, Rijksuniversiteit Limburg.- (ROA-W, ISSN 0922-4645; 1991/2E)

Met lit. opg.

ISBN 90-5321-060-1 in spiraalband

Trefw.: onderwijs en arbeidsmarkt : informatiesystemen. 
CONTENTS

Page

SUMMARY

1. INTRODUCTION

2. THE SET-UP OF THE INFORMATION SYSTEM

3. THE RISK-INDICATORS

4. THE LABOUR MARKET FORECASTS

5. FOCUSES OF ATTENTION FOR FURTHER DEVELOPMENT 


\section{SUMMARY}

The Research Centre for Education and Labour Market, part of the Faculty of Economic Sciences of the University of Limburg, was established in mid 1986 on the basis of a contract from the Dutch Ministry of Education and Science to develop an information system on education and the labour market. Through this project the Ministry aimed to fill the need for a research centre which continually analyses and forecasts developments in education and on the labour market, so that developments in the two fields can be correlated. The commission for the project was set out in more detail with the stipulation of the Ministry that the system developed should be suitable for supplying information about study and professions to pupils and to students in further and higher education. In addition, the information system should contribute to the improvement of capacity planning in education and the utilization of the population's investment in knowledge and skills, so as to enhance economic potential.

After a first version which related solely to the labour market for university qualifications, a new version of the Information System on Education and the Labour Market, covering the entire labour market and the entire educational system, appeared in 1989. The system provides three types of information about the relation of education to the labour market:

- statistical data giving the current situation;

- risk indicators relating to the cyclical sensitivity of employment prospects in the different occupational classes and the possibilities, according to labour market qualification, of lateral movements into other occupations or fields;

- forecasts over a period of five years of employment levels, replacement demand, the flow of school leavers into the labour market and the resulting discrepancies between the number of job openings and the 'output' of the education system.

The data in the system is categorised into 23 sectors of industry, 79 occupational classes, and 53 types of education.

The structure of the Information System on Education and the Labour Market is first explained in more detail, with an illustration of the data available, and then some focuses of attention for the further development of the system are described. 


\section{INTRODUCTION}

The Research Centre for Education and Labour Market (ROA), part of the Faculty of Economic Sciences of the University of Limburg, was established in mid 1986 on the basis of a contract from the Dutch Ministry of Education and Science to develop an information system on education and the labour market. Through this project ${ }^{1}$ the Ministry hoped to meet the need for a research centre which would continually analyze and forecast changes in education and on the labour market, so that developments in the two fields can be correlated. The research should ideally cover the entire field of education and the entire labour market, and, as well as conducting empirical research, particular attention would be given to the theoretical foundations of such research.

The requirements for the project were set out in more detail with the stipulation of the Ministry that the system developed should be suitable for supplying information about study and professions to pupils and to students in further and higher education. In addition, the information system should contribute to the improvement of capacity planning in education and the utilization of the population's investment in knowledge and skills, so as to enhance economic potential.

The first version of the Information System on Education and the Labour Market, covering only university education, was ready in $1987 .{ }^{2}$ University education was chosen because of a growing cooperative relationship with the "I-See!"-project, which had meanwhile started. This project aimed at the development of an automated system for study and occupational choice. I-See! was built up out of three modules: an education and training module, an occupation module and a labour market module. ${ }^{3}$ ROA supplied the data for the labour market module. The pilot phase of I-See! was limited to university education. In order to match ROA's research properly to the development of I-See! it was therefore appropriate to also limit the preliminary version of the Information System on Education and the Labour Market to university education.

After the pilot phase, I-See! was broadened to cover all types of education. At the same time, ROA extended its Information System on Education and the Labour Market to cover the all further and higher education. At the end of 1989 the new, extended version of the information system was ready. ${ }^{4}$ The system proccesses three kinds of information about the relation of education to the

1. See Heijke (1986) for a full description of the project.

2. For a summary and systematic description, cf: De Grip, Heijke, Dekker and Groot (1987).

3. The name I-See! stands for "Information System on Education and Employment".

4. See De Grip, Heijke and Dekker, (1989). 
labour market:

- statistical data giving the current situation;

- risk indicators relating to the cyclical sensitivity of employment prospects in the different occupational classes and the possibilities, according to labour market qualification, of lateral movements into other occupations or fields;

- forecasts over a period of five years of employment levels, replacement demand, the flow of school leavers into the labour market and the resulting discrepancies between the number of job openings and the 'output' of the education system.

The data in the system is categorised into 23 sectors of industry, 79 occupational classes, and 53 types of education. As a result of the ongoing cooperation with the I-See!-project, the data of ROA's Information System on Education and the Labour Market have been included in I-See!, which has meanwhile reached the operational stage. In 1990 the information system was updated and adjusted in connection with the second release of I-See!. Among other things, the forecasting period was changed from 1985-1992 to 1989-1994.

ROA has meanwhile developed into a research institute with a staff of 20 . The institute is financed entirely by revenues from contract research. This research is not limited to the Information System on Education and the Labour Market, the basis on which ROA was founded. The new research projects can be roughly divided into (1) projects aimed at broadening the supply of data relating to the matching of education to the labour market and (2) projects in which the education-labour market matching problem is examined for specific types of education, occupations, economic sectors or regions. Two examples from the first category are the contributions ROA has made to the establishment of a national survey of school leavers from further education about their position in continuing training or on the labour market, and the development of a labour market scanner that will follow higher education graduates in their career paths over both short and long terms. Two examples from the second category are investigations into the labour market prospects for clinical psychologists and for researchers. Although these projects are conducted within other frameworks, the possibility of a link with the Information System on Education and the Labour Market is continuingly checked.

Apart from the research activities mentioned above, ROA has a specified teaching role in the Faculty of Economics of the University of Limburg. This task includes among other things the supervision of dissertations, theses and the practical (research) component of course work. The teaching role is related so far as possible to research activities, so that they can support each other. 
$-3-$

This paper is intended to give an impression of the main project of the ROA: the development of the Information System on Education and the Labour Market. In the next section, the set-up of the system is discussed. The following two sections illustrate the information available, beginning with the risk indicators and followed by labour market forecasts. In the final section some focuses of attention for the further developments of the system are described. 


\section{THE SET-UP OF THE INFORMATION SYSTEM}

The Information System on Education and the Labour Market can be described on the basis of the diagram. The top part of the diagram relates to the main assumptions and externally formulated forecasts which form the basis of ROA's labour market forecasts. Below these, the general structure of the system is represented. The system is built up in three layers. The top layer concerns data by sectors of industry, the middle layer is concerned with the occupations part of the information system and the bottom layer represents the educations part.

In the introduction it has already been indicated that the Information System on Education and the Labour Market has three categories of data: statistical data on the present situation, risk indicators, and medium-term labour market forecasts. This description of the system will only deal with the forecasts and the risk factors.

The forecasts of changes in employment levels are in fact the most complex part of the information system. Along with forecasts of replacement demand and of the flow of school leavers into the labour market, employment forecasts form an essential part of an information system that is in part aimed at supplying adequate information for study and occupational choices. For the system to be used for this purpose, it is essential that information on the labour market prospects of education types or occupations be given for the medium long term. The medium long term is important because this is usually the interval between choosing an education path and going, with the qualification obtained, in search of a first job. Because of this long response-time, if education decisions are made on the basis of the signals received from the present labour market situation rather than the future situation this may cause 'cobweb dynamics' in the labour market.

The forecasts of employment levels in the information system extend the medium term forecasts of labour volume according to sector of industry made by the Dutch Central Bureau for Planning (CPB). On the basis of CPB forecasts of changes in the average hours (proportion of full-time equivalent) of each employment postion, the labour volume forecast is converted to numbers of workers per sector of industry. These are then divided, for each sector of industry, over the occupational classes which have been defined. Finally, taking into account the expected shifts in the industry and occupational class structures, the employment forecasts for the different education types are determined. This approach guarantees that the educational and occupational employment forecasts are consistent. 


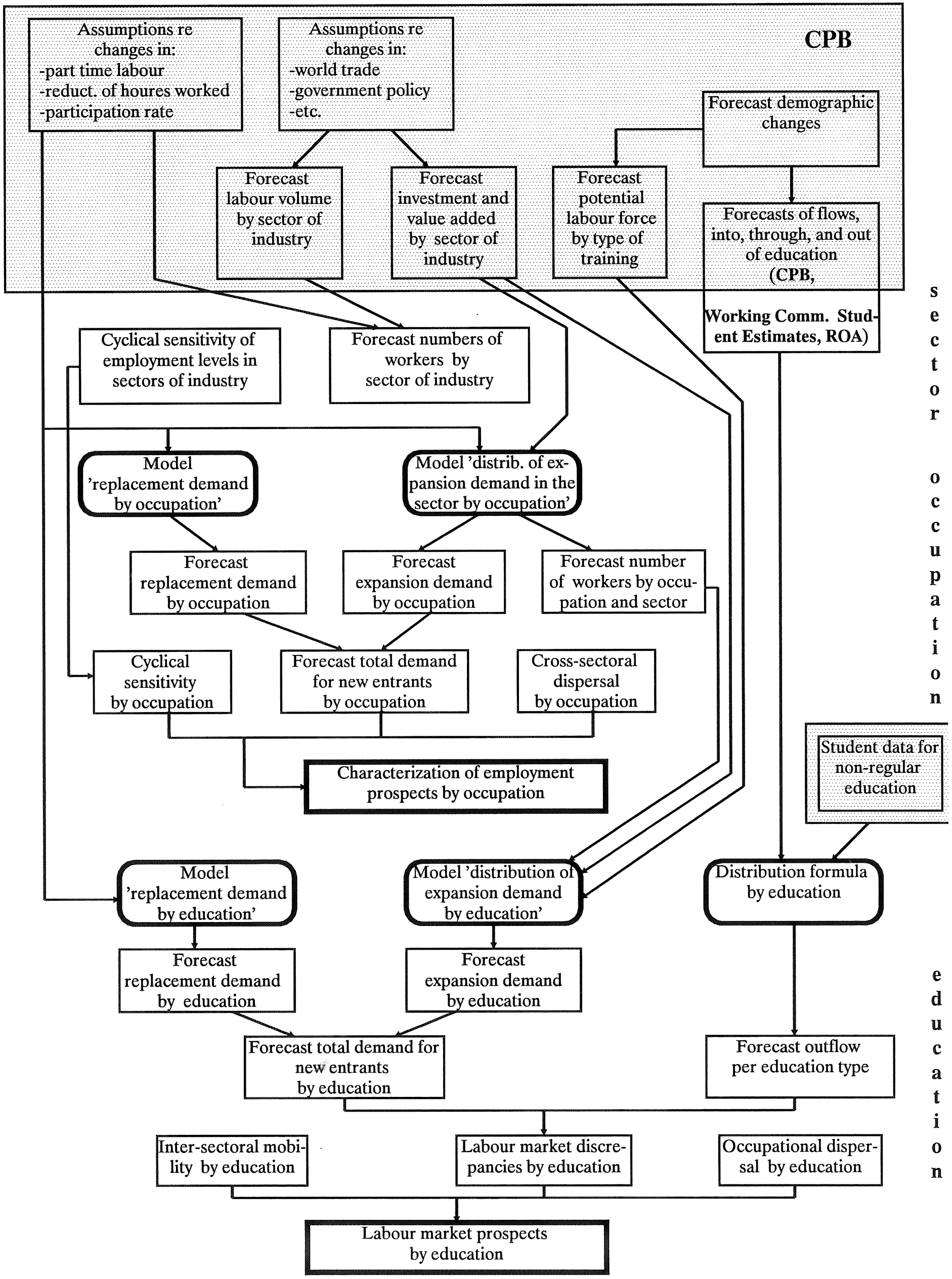


The econometric models that underlie the forecasts of the occupational and educational structure of employment, differ from the traditional manpower planning models in that they are not based simply on extrapolations from perceived trends, but are drawn up on the basis of explanatory models. The data of the educational and occupational structure that are used to estimate these models is drawn, for the period 1975-1985, from the biennial Labour Force Survey (Arbeidskrachtentelling) of the Dutch Central Bureau for Statistics (CBS).

The basic assumption in the design of the occupational mode/ ${ }^{5}$ is that the occupational structure of a sector of industry forms an aspect of the demand side of the labour market. The development of the occupational structure of employment in each sector of industry is therefore explained in the model by factors that influence especially the demand for labour. Apart from technological development (capital-intensity of the production process, degree of automation), cyclical factors (capacity utilization) and more structural (trend) effects are also entered in the model as explanatory variables.

The educational mode ${ }^{6}$ has two steps: the first distinguishes only between levels of education, while in the second step a distinction is made within each level between the different fields of education. This allows for the assumption that the educational structure of occupations in a sector of industry may be influenced by demand as well as supply factors. In the first step, technological developments (capital-intensity and degree of automation) are entered as explanations for shifts in the required level of qualification. Where new technologies are used, an upgrading or downgrading of the required level of education in an occupational class may occur. However, shifts in the skill level of occupations may also be brought about by supply factors. In an easy labour market, the less educated may be pushed out of their 'occupational domain' by more educated workers. From the point of view of the neoclassical economic theory this crowding out can be explained by a relative scarcity of workers with a certain skill level. However, the substitution between skill levels could then occur in an upward as well as a downward direction. Because of the lack of adequate data on wages, the share of persons with a certain skill level in the total potential labour force was chosen as a measure of the extent of the substitution processes initiated by the supply side of the labour market. To determine the share of a field of education within a certain education level, it is necessary to fall back on a simple model with only one term for trends.

Along with increases in employment levels, the future replacement demand because of the departure of personnel is also very important in determining the number of jobs that become

5. See: Dekker, De Grip and Heijke (1990) and Peeters (1990).

6. See: Beekman, Dekker, De Grip and Heijke (1989), and Peeters (1990). 
available for new entrants on the labour market. The replacement demand is the result on the one hand of permanent retirement from the labour force because of retirement, early retirement, etc. and on the other hand often temporary withdrawals, especially by married women who care for and raise their own children.

To determine replacement demand ${ }^{7}$, a forecast is first made of the replacement requirement of the different occupational classes, on the basis of various factors including the predicted participation rate of the various age cohorts according to sex, the historical personnel turnover of the various age cohorts (according to sex) in the occupational classes concerned, and the age structure of the working population according to occupation in the base year of the forecasts. Moreover, a correction allows for possible distortion in personnel turnover as a result of cyclical fluctuations in employment. The replacement demand by type of education is determined with the aid of (reconstructed) data on the age structure of the labour force according to type of education.

By adding the employment forecasts to the forecasts of replacement demand, the number of the expected future job-openings is obtained. The latter is related to the number of school leavers entering the market, to indicate what their prospects may be. The forecasts of the supply of school leavers in the Information System on Education and the Labour Market are based on external estimates from the CPB, using the SKILL-model, (for the lower levels) and from the Working Committee on Student Estimates of the Ministry of Education and Science (for the higher levels). These estimates are not complete and sometimes not sufficiently detailed for the information system. Where necessary they are therefore corrected and elaborated by the ROA. Moreover, estimates of the effects on the educational structure of labour supply as a result of non-regular education are added.

The prospects of school leavers with a certain type of education on the labour market are indicated in the information system by means of a labour market indicator. This indicator is determined on the basis of forecasts of the number of 'job-openings', the predicted influx of school leavers, and employment and unemployment at the beginning of the forecasting period. The indicator of the future labour market situation (IFL) is given in formulaic form as follows:

$\mathrm{IFL}=\frac{\text { working ('89) }+ \text { influx ('89-'94) + unemployed ('89) }}{\text { working ('89) + expansion demand ('89-'94) + replacement demand ('89-'94) }}$

7. See Willems and De Grip (1990). 
$-8-$

This indicator is calculated for every educational category. When supply and demand are balanced in the market segment in question, the indicator is 1 . To assist choices of study and occupation, the IFL scores of the market for various types of education are translated into the qualifications 'good', 'reasonable', 'average' or 'bad' labour market prospects.

In addition to the labour market forecasts, two risk indicators are entered in the information system. These risk indicators give an indication of the cyclical sensitivity of employment in a certain occupational class and of the possibilities of switching to another occupation (lateral mobility) or another sector of industry (inter-sectoral mobility), indicating the labour market flexibility of the group concerned. The trend of the dispersal index is also entered in the information system.

The cyclical sensitivity ${ }^{8}$ of occupations is measured as follows. For every sector of industry the following fluctuation-index is calculated:

$$
F I_{s}=\frac{100}{H} \sum_{t=1}^{H} \frac{\left|F_{s t}\right|}{T_{s t}}
$$

where:

$$
\begin{array}{ll}
F I_{S} & =\text { cyclical sensitivity index for sector } \mathrm{s} ; \\
F & =\text { divergence of employment from the trend value; } \\
T & =\text { trend value of employment; } \\
H & =\text { number of observation years; } \\
t & =\text { year. }
\end{array}
$$

The trend values are determined by taking the five-year moving average of employment in the sector, over the period 1950-1988.

Supposing that employment in the various occupations within an occupational class fluctuates to the same degree as the total employment in the sector of industry (a supposition that is not entirely reliable ${ }^{9}$ ), a fluctuation index for each occupation may be derived by weighting the fluctuationindices of the various sectors of industry by the portion of the occupational class active in that sector in 1985.

8. See De Grip and Heijke (1988), pp 6-8 and De Grip, Heijke and Dekker (1989) pp 32-34.

9. Cf the structure of the occupational model in Dekker, De Grip and Heijke (1990). 
$F I_{\circ}=\sum_{S=1}^{S} \alpha_{o s} F I_{S}$

where:

$F I_{0} \quad=$ cyclical sensitivity index for occupation 0 ;

$\alpha_{o s} \quad=$ share of occupation o working in sector $s$;

$S \quad=$ number of sectors.

The possibility of lateral mobility ${ }^{10}$ from a given education to other occupations is calculated by means of the 'Gini-Hirschman' coefficient, as follows:

$G H_{d}=\left(1-\sum_{0=1}^{0} \beta_{d o}^{2}\right) \frac{0}{0-1}$

where:

$\mathrm{GH}_{d} \quad=$ dispersion index of educational type d;

$\beta_{d o} \quad=$ portion of educational type d active in occupation o;

$0=$ number of occupations.

This indicator can take values between 0 and 1 . The value is 0 if the educational type is found in only one occupation, and 1 if the education is dispersed equally over all occupations.

These risk-indicators are a very important addition to the labour market forecasts. For example, high occupational dispersal will make medium to long-term forecasts rather conditional, because, in the event of excess supply, it would be expected to be relatively easy for those in this educational group to shift to other segments of the labour market. The cyclical sensitivity indicator may also relativize medium to long term forecasts. If high employment growth is forecast for an occupational class with high cyclical sensitivity, the possibility has to be taken into account that this growth could be sharply reduced in the longer term, or even that it could turn into a decrease of employment.

10. See De Grip and Heijke (1988), pp 8-11 and De Grip, Heijke and Dekker (1989), pp 34-39. 


\section{THE RISK-INDICATORS}

In this section an impression will be given of the data available in the Information System on Education and the Labour Market in relation to the cyclical sensitivity risk-indicators of occupations and the mobility potentials of educational types. ${ }^{11}$ The data presented will be limited to those cases that score very high or low for the indicator in question.

Tables 3.1 and 3.2 present the ten occupational classes with the widest and narrowest employment fluctuations. Many industrial and building trade occupations are among those most sensitive to the business cycle; service occupations, on the contrary, appear to be relatively stable.

Table 3.1. Occupational classes with the greatest cyclical sensitivity (1950-1988)

$\begin{array}{lll}\text { code } & \text { occupational class } & \mathrm{FI}_{0} \%\end{array}$

71 Miners, quarrymen, well drillers and related workers 38

$95 \quad$ Bricklayers, carpenters and other construction workers 21

83 Blacksmiths, toolmakers and machine tool operators 19

93 Painters 19

72 Metal processors $\quad 18$

87 Plumbers, welders, sheet metal and structural metal preparers and erectors 18

$85 \quad$ Electrical fitters and related electrical and electronics workers 17

99 Labourers not included elsewhere 17

70 Production supervisors and general foremen 16

$74 \quad$ Chemical processors and related workers 16

Source: ROA

Table 3.2. Occupational classes with the least cyclical sensitivity (1950-1988)

$\begin{array}{lll}\text { code occupational class } & \mathrm{Fl}_{\mathrm{o}} \%\end{array}$

61 Farmers 4

64 Fishermen, hunters and related workers 4

06 Medical, dental, veterinary and related workers $\quad 5$

62 Agricultural and animal husbandry workers $\quad 5$

$05 \quad$ Life scientists and related technicians 6

13 Teachers 6

$51 \quad$ Working proprietors (catering and accommodation services) 6

57 Hairdressers, barbers, beauticians, and related workers 6

59 Service workers not included elsewhere 6

60 Farm managers and supervisors $\quad 6$

Source: ROA

11. These data are taken from De Grip, Heijke and Dekker (1989). 
Tables 3.3 and 3.4 present the educational groups with the widest and narrowest occupational dispersion, respectively. Predictably, a general education can be observed from the tables to have a wide occupational dispersion. The same can be said of technical and administrative (lower and intermediate) educational groups. Except for one non-regular course, business security and surveillance training, all educational groups with a narrow occupational dispersion are on the intermediate and higher levels. Once more, these are almost all courses specifically for certain public-sector occupations.

Table 3.3. Educational groups with the highest occupational dispersion (average 1979-1985)

\begin{tabular}{llc} 
code & educational group & $\mathrm{GH}_{\mathrm{d}}$ \\
\hline 331 & Lower technical education & 0.95 \\
436 & Technical education (I) & 0.95 \\
301 & General secondary education, lowest level & 0.93 \\
441 & Transport education (I) & 0.93 \\
461 & Economic and administrative education (I) & 0.93 \\
401 & General secondary education, highest level & 0.92 \\
361 & Lower administrative and commercial education & 0.91 \\
381 & Lower domestic and catering education & 0.91 \\
521 & Agricultural studies (SH) & 0.90 \\
561 & Economic and administrative education (SH)
\end{tabular}

Source: ROA

$\mathrm{I}=$ Intermediate level; $\mathrm{SH}=$ Semi-high level; $\mathrm{H}=$ Higher level.

Table 3.4. Educational groups with the lowest occupational dispersion (average 1979-1985)

code educational group $\mathrm{GH}_{\mathrm{d}}$

$651 \quad$ Medical sciences $(\mathrm{H}) \quad 0.22$

$606 \quad$ Teacher education $(\mathrm{H}) \quad 0.26$

$551 \quad$ Nursing and physiotherapy training and related studies (SH) 0.29

$454 \quad$ Medical care education (I) 0.36

$\begin{array}{lll}506 & \text { Teacher education (SH) } & 0.37\end{array}$

$516 \quad$ Pastoral studies (SH) 0.41

$391 \quad$ Lower security training $\quad 0.42$

$\begin{array}{lll}616 & \text { Theological studies }(\mathrm{H}) & 0.49\end{array}$

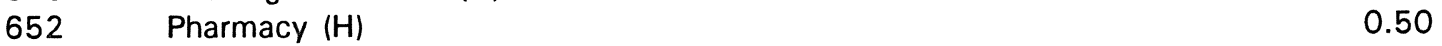

$451 \quad$ Nursing training (I) $\quad 0.51$

Source: ROA

$\mathrm{I}=$ Intermediate; $\mathrm{SH}=$ Semi-high level; $\mathrm{H}=$ Higher level. 
Table 3.5. gives a general survey of the observed occupational dispersion of graduates, differentiated according to educational level and a limited number of broad subject categories. The indicators given here have been calculated on the basis of a more detailed classification of educational types that is also used in tables 3.3. and 3.4. The table gives the maximum and minimum values of the indicator for each broad educational category.

The table shows that the indicator is highest for general types of education. Here the minimum and maximum coincide, because within this category no sub-fields were distinguished within a.level. Furthermore, the table shows that the value of the indicator is lowest for the 'service' fields, that is for education in medical and educational fields etc which is strongly oriented to specific occupations in the public sector. The vulnerability of the graduates in these educational fields to changes in the labour market situation in their specific occupational domain is therefore considerable. The limited alternative possibilities for these types of education, combined with the slow response of the supply of new graduates due to the long training period, mean that periods of high supply surpluses alternate with periods with large shortages, as can theoretically be explained by the 'cobweb theorem'.

Table 3.5. Occupation dispersion per educational sector (educational classification of the CPB)

\begin{tabular}{lll}
\hline educational category & minimum & maximum \\
\hline Elementary & & \\
general & 0.97 & 0.97 \\
Lower & & \\
general & 0.93 & 0.93 \\
technical & 0.74 & 0.95 \\
administrative & 0.91 & 0.91 \\
services & 0.42 & 0.92 \\
Intermediate & & \\
general & 0.92 & 0.92 \\
technical & 0.76 & 0.95 \\
administrative & 0.75 & 0.93 \\
services & 0.36 & 0.86 \\
Semi-high & & \\
technical & 0.70 & 0.91 \\
administrative & 0.84 & 0.90 \\
services & 0.29 & 0.89 \\
Higher & & \\
technical & 0.68 & 0.82 \\
administrative & 0.70 & 0.86 \\
services & 0.22 & 0.79 \\
\hline Source: & &
\end{tabular}

Source: ROA 
$-13-$

It is also remarkable that for a given field of education, the dispersion decreases as the educational level becomes higher. This result contradicts the widely held belief that those with higher education have more labour market flexibility than the less educated. On the contrary, the higher types of education appear to be more specialized than the lower educational types. These results also show that entrants to the labour market with higher education do not fall back on previously received lower diplomas. 


\section{THE LABOUR MARKET FORECASTS}

This presentation of the Information System on Education and the Labour Market's forecasts, first by occupational group and then by types of education, will, like the section on risk-indicators, be limited to the extreme cases ${ }^{12}$. The forecasts by occupational class relate only to employment opportunities. The forecasts by educational types, in contrast, can be compared to data on the supply side of the labour market. This will be done by means of the labour market indicator mentioned in section 2 .

Table 4.1 shows the predicted occupational winners in the first half of the 1990 s. The list of greatest winners in an absolute sense is headed by the very heterogeneous occupational class 'freight handlers and concrete batchers etc.'

Table 4.1. Occupational winners (absolutely seen): forecasts 1989-1994

Employment increase

Occupational class

Absolute number

$\%$

Freight handlers, concrete batchers, etc.

47,000

25

Software analysts, statisticians, etc.

45,000

57

$3 \quad$ Managerial and higher executive employees

(excl. public administration)

42,000

20

Shop assistants

30,000

10

4

Mail distribution employees

22,000

36

Engineers and related technicians

21,000

Physicians and other medical workers

20,200

Bank employees, etc

13,000

Self-employed shopkeepers

12,000

Miscellaneous administrative workers

11,000

11

7

4

12

10

Source: ROA

The list of the greatest winners, relatively seen, is headed by the occupational class software analysts, statisticians etc. (see table 4.2).

12. The information given is taken from De Grip and Heijke (1991). 
Table 4.2. Occupational winners (relatively seen): forecasts 1989-1994

Employment increase

Occupational class

Absolute number

$\%$

\begin{tabular}{rlrr}
\hline & & & \\
1 & Software analysts, statisticians, etc & 57 & 35 \\
2 & Mail distribution employees & 25,400 & 26 \\
3 & Journalists, authors & 7,400 & 25 \\
4 & Freight handlers, concrete batchers, etc & 47,000 & 20 \\
5 & Managerial and higher executive employees & 42,300 & 12 \\
6 & Self-employed shopkeepers & 12,300 & 12 \\
7 & Managers wholesale trade, etc & 4,600 & 12 \\
8 & Self-employed commercial agents & 3,500 & 12 \\
9 & Managers retail trade & 2,100 & 11 \\
10 & Engineers and related technicians & 21,200 & \\
\end{tabular}

Source: ROA

The occupational classes that can be described as the occupational losers in the first half of the 1990s are shown in table 4.3. The losers' list is headed by the sales supervisors and buyers, for which an employment decrease of almost $20 \%$ is forecast. Other classes for which a severe employment decrease is expected are blacksmiths, tool-makers and telephone and telegraph operators.

Table 4.3. Occupational losers (absolutely seen): forecasts 1989-1994

Employment decrease

\begin{tabular}{rlrr} 
& Occupational class & Absolute number & $\%$ \\
1 & & & 18 \\
2 & Sales supervisors and buyers & 7,000 & 14 \\
3 & Blacksmiths, tool-makers & 4,000 & 3 \\
4 & Self-employed farmers & 3,500 & 23 \\
5 & Telephone and telegraph operators & 3,500 & 5 \\
6 & Shoemakers, etc & 3,500 & 2 \\
7 & Bricklayers and carpenters & 3,000 & 2 \\
8 & Agricultural workers & 2,500 & 5 \\
9 & Printers and related workers & 2,000 & 1 \\
10 & Drivers and sailors & 1,500 & 1 \\
\hline
\end{tabular}

Source: ROA

The relative decrease for these classes can be seen in the second column. There are some small occupational classes with a predicted absolute loss of less than a thousand, but a relative loss which is higher than those shown here. However no table of relative losses, which would include these small categories, is given here, since, given the various uncertainties, forecast employment losses of less than 1,000 cannot be taken as meaning that a class is an occupational loser. 
To give an impression of the expected developments in labour demand in the first half of the 1990s, the educational groups for which the ROA forecasts indicate the highest and the lowest numbers of relative job openings, are presented in table 4.4 and 4.5 respectively. As has been said before, these job openings consist of two components: employment increases and replacement demand.

Relatively seen the greatest number of job openings are forecast for graduates in econometrics and technical management (management science at technical universities). Technical sciences at an academic level also feature on this list. For economic and administrative education, at both intermediate and semi-high level, relatively large numbers of job openings are also expected. Four studies at intermediate level - social and welfare work education, medical care studies, nursing training, and medical laboratory education - are the only types of education on this list for which the replacement demand component dominates in the number of job openings forecast. All these studies are characterized by an over-representation of females and are related to occupational classes that traditionally show large replacement demands. In absolute terms a large number of job openings is also expected for lower technical education and general secondary education (lowest level). In both categories replacement demand is dominant: $100 \%$ and $64 \%$, respectively.

Table 4.4. Educational groups with the most job openings (as a percentage of employment in 1989), divided into replacement demand and employment growth)

Type of education

job openings

$\%$ replacement demand

$\%$ employment increase $\%$
Econometrics and technical management $(\mathrm{H})$

Economic and administrative education (I)

Social and welfare work education (I)

Economic and administrative education $(\mathrm{SH})$

Lower transport training

Medical care studies (I)

Technical management and ergonomics (SH)

Nursing training (I)

Medical laboratory education (I)

Technical sciences $(\mathrm{H})$

\section{4}

31

29

29

27

24

23

21

21

21
92

85

38

86

68

40

77

42

48

72

Source: ROA

$\mathrm{I}=$ Intermediate level; $\mathrm{SH}=$ Semi-high level; $\mathrm{H}=$ Higher level.

A very low relative number of job openings is forecast for those educational groups in particular that suffer from a lack of new positions. Apart from the unskilled workers with only elementary education and lower agricultural and security training, the presence of several types of higher and semi-high education on this list is quite remarkable (see table 4.5). For most types of education on 
this list, the majority of the job openings relate to replacement demand.

Table 4.5. Educational groups with the fewest job openings (as a percentage of employment in 1989): forecasts 1989-1994 (divided into replacement demand and employment growth)

\begin{tabular}{lccc} 
Type of education & job openings & $\begin{array}{c}\text { replacement } \\
\text { demand } \\
\%\end{array}$ & $\begin{array}{c}\text { employment } \\
\text { increase } \\
\%\end{array}$ \\
\hline Lower security training & $\%$ & 100 & - \\
Interpreters and translators education (SH) & 3 & 100 & - \\
Elementary education & 5 & 100 & - \\
Art studies (SH) & 6 & 100 & 40 \\
Teacher education (H) & 7 & 60 & - \\
Lower agricultural education & 7 & 100 & 34 \\
Language and cultural studies (H) & 8 & 65 & 50 \\
Legal and administrative education (I) & 8 & 95 & 40 \\
Law and administrative sciences (H) & 9 & 40 & 60 \\
Socio-cultural sciences (H) & 10 & 60 & -
\end{tabular}

Source: ROA

$\mathrm{I}=$ Intermediate level; $\mathrm{SH}=$ Semi-high level; $\mathrm{H}=$ High level.

Now the most severe mismatches between supply and demand for workers, according to the various educational groups which have been distinguished, will be highlighted. The forecast of the labour market prospects of educational groups in the first half of the 1990s shows that these prospects will probably be quite different for the various groups. Table 4.6 presents the educational groups that will probably face excess demand in the middle of the 1990s. The 'IFL' indicator given is the quotient of the supply and demand forecasts as defined in section 2. Although the figures presented are quite exact, they should be interpreted with care. One can say no more than that they give an indication of the future labour market situation. For the more skilled groups the indicator does not express an expected level of unemployment, as these groups will probably find jobs at lower levels. However, that does not mean that the labour market for these groups should not be described as having an excess supply.

Excess demand is forecast for workers with transport education at all levels, economic and administrative education and medical laboratory education at intermediate and semi-high level, theological and pastoral studies at higher and semi-high level, and police and military training at 
Table 4.6. Types of education that will probably face excess demand (forecasts 1989-1994)

Labour market

indicator (IFL)*

Lower transport training

Economic and administrative education (I)

Theological studies $(\mathrm{H})$

Transport education (I)

0.98

Lower domestic and catering education

0.99

Pastoral studies (SH)

1.00

Medical laboratory education (SH)

1.00

Economic and administrative education (SH) 1.00

Police and military training(I)

1.01

General secondary education, lowest level $\quad 1.01$

Medical laboratory education (I) 1.01

Legal and administrative education (I) $\quad 1.02$

$\begin{array}{ll}\text { Transport education (SH) } & 1.04\end{array}$

Source: ROA

$\mathrm{I}=$ Intermediate level; $\mathrm{SH}=$ Semi-high level; $\mathrm{H}=$ Higher level.

* A value of 1.05 indicates an equilibrium of supply and demand, labour market frictions included.

intermediate level. However, two less skilled educational groups on the list - lower domestic and catering education and general secondary education at the lowest level - indicate that in the near future some less skilled groups will face excess demand. Probably this is due to the expected decrease in the entry of less skilled young people onto the labour market. However, as the forecast also indicates that workers with a general secondary education at a higher level will face severe excess supply (see table 4.7), one would expect that further substitution of workers with intermediate level general skills for less skilled workers will probably diminish excess demand for the groups of less skilled workers mentioned.

It is striking that higher and semi-higher educational groups dominate in the list of educational groups for which severe excess supply is forecast (table 4.7): languages and cultural studies, agricultural sciences, law and administrative sciences, art studies, socio-cultural sciences, and nursing and physiotherapy training and related studies. Although, as has been said before, this does not imply that unemployment for these groups will become extremely high, it still gives an indication that these groups will face severe excess supply. For unskilled workers with only an elementary education the labour market prospects are also quite bad, especially because these workers have hardly any opportunity to 'bump down' other educational groups out of employment. At intermediate level, only social and welfare work education is expected to face excess supply. 
$-19-$

Table 4.7. Types of education that will probably face severe excess supply: forecasts 1989-1994

Type of education

Labour market

indicator (IFL)*

Languages and cultural studies $(\mathrm{H})$

1.80

Agricultural sciences $(\mathrm{H})$

1.64

Agricultural studies (SH)

1.64

Social and welfare work education (I)

1.63

Law and administrative sciences $(\mathrm{H})$

1.62

Elementary education

1.52

Art studies $(\mathrm{SH}, \mathrm{H})^{*}$ *

1.49

Socio-cultural sciences $(\mathrm{H})$

1.48

Nursing and physiotherapy training, and related studies $(\mathrm{SH})$

1.47

General secondary education, highest level

1.43

Lower security training

1.44

Source: ROA

$\mathrm{I}=$ Intermediate level; $\mathrm{SH}=$ Semi-high level; $\mathrm{H}=$ Higher level.

* See table 4.6

* For the very small group Art studies $(\mathrm{H})$ we calculated an indicator of 2.62 


\section{FOCUSES OF ATTENTION FOR FURTHER DEVELOPMENT}

As the Information System on Education and the Labour Market is developed further, special attention will be given to the six areas described below. The first area concerns the improvement of the statistical data base that is used in calculating the risk indicators and making labour market forecasts. One important activity in this regard is the linking of an old series of labour market data from the Labour Force Surveys held until 1985 to a new series that will be built up from the Labour Force Census which will only give usable results since 1990. Although these sources of data cover the entire labour market, they do not give sufficient detail. Therefore additional and more detailed sources will be used, such as the school leavers questioneers in further education and the labour market scanner in higher education. Apart from a larger degree of detail, the relevant distinction between first jobs and career paths could be introduced in the information system.

The second area concerns the implementation of a new classification of occupations with a higher labour market relevance than that of the CBS. This new classification is based on an analysis done by the ROA, in which occupations were grouped on the basis of the educational field and the skill level of those working in the occupation. ${ }^{13}$

The third area demanding attention is the improvement of the specification of the mode/s and riskindicators used, and the testing of other techniques to estimate the parameters of these models. The estimates for of the models of the occupation structure of sectors of industry and of the educational structure of occupations in sectors are currently being worked out, using multinomial logit. ${ }^{14}$

The fourth area concerns the regionalization of the Information System on Education and the Labour Market. At present the system contains only national data. To obtain a good picture of the correlation of education and the labour market, however, a regional point of view is essential. This applies especially to the functioning of the labour market segments for those with lower and intermediate education. To provide information for choices of study and occupational choice, and to formulate labour market policy, nation-wide information needs to be supplemented by regional information. With this in mind, the possibilities of specifying various elements of the Information System on Education and the Labour Market (data on the present situation, indicators, and forecasts) by region is being investigated.

13. De Grip, Groot and Heijke (1991).

14. For the first results see Peeters (1990). 
Graduates from higher education will increasingly orient themselves to the international labour market. In the light of the lifting of the border restrictions in 1992, European countries, in particular, will be increasingly important. For the lower-level types of education the possibility that the labour markets in the border regions will cross national borders must be particularly kept in mind. In order to be able to anticipate these developments, the fifth area of attention will be an endeavour to participate in an international network of institutes that conduct analyses comparable to those done by the ROA, so that the Information System on Education and the Labour Market can be integrated, via this network, in an information system with international labour market information.

The sixth and last focus of attention concerns the necessity of evaluating the Information System on Education and the Labour Market. ${ }^{15}$ On the one hand, it should be said that it is important to regularly sound out the needs of the various target groups and the user value of the information system for these target groups. On the other hand it is desirable that we systematically evaluate the forecasting results ourselves. Apart from an ex post evaluation of these results, the establishment of a network of specialized institutes that can give ex ante judgements of the plausibility of the various forecasting results is being considered.

15. A first evaluation report has meanwhile been edited: De Grip, Heijke and Berendsen (1991). 


\section{REFERENCES}

Beekman, Th.B.J., R.J.P. Dekker, A. de Grip, J.A.M. Heijke (1989), An Explanation of the Educational Structure of Occupations, ROA-W-1989/3E, Maastricht.

Dekker, R.J.P., A. de Grip, J.A.M. Heijke (1990), An Explanation of the Occupational Structure of Sectors of Industry, in: Labour, volume 4, no. 3.

Grip, A. de, J.A.M. Heijke, R.J.P. Dekker, L.F.M. Groot (1987), Labour Market Prospects for Occupations and Academic Studies in 1992, ROA-W-1987/1E, Maastricht.

Grip, A. de, J.A.M. Heijke (1988), Labour Market Indicators: an Inventory, ROA-W-1988/1E, Maastricht.

Grip, A. de, J.A.M. Heijke, R.J.P. Dekker (1989), The Labour Market by Education and Occupation in 1992, ROA-R-1989/8E, Maastricht.

Grip, A. de, J.A.M. Heijke (1991), Past and Future Shifts in Labour Supply and Demand by Education and Occupation, Maastricht.

Grip, A. de, L.F.M. Groot, J.A.M. Heijke (1991), Defining occupational groupings by educational structure, in: Environment and Planning A, volume 23, pp. 59-85.

Grip, A. de, J.A.M. Heijke, H. Berendsen (1991), Eerste evaluatie informatiesysteem onderwijsarbeidsmarkt, ROA-R-1991/1, Maastricht.

Heijke, J.A.M. (1986), The Research Centre for Education and Labour Market, ROA-R-1986/1E, Maastricht.

Peeters, H.M.M. (1990), An Explanation of the Occupational and Educational Structure of Employment by Means of Multinomial Logit, ROA-W-1990/4E, Maastricht.

Willems, E.J.T.A., A. de Grip (1990), Replacement Demand Forecasts by Occupation and Education, ROA-W-1990/7E, Maastricht. 